\title{
Recycling programs in partnership with scavenger associations as a sustainability factor in Metropolitan São Paulo, Brazil
}

\author{
H. Ribeiro ${ }^{1}$, G. R. Besen ${ }^{1}$, W. R. Günther ${ }^{1}$, P. Jacobi ${ }^{2}$ \\ \& J. Demajorovic ${ }^{3}$ \\ ${ }^{1}$ Public Health School (Department of Environmental Health), \\ University of São Paulo, Brazil \\ ${ }^{2}$ School of Education, University of São Paulo, Brazil \\ ${ }^{3}$ University Center Senac, São Paulo, Brazil
}

\begin{abstract}
The aim of this research was to evaluate waste recycling programs in partnership with scavenger associations in Metropolitan São Paulo, to verify their social, economic, sanitary, and environmental impacts in a sustainability perspective. Methods included bibliographical and data research and structured interviews with representatives of 39 municipalities. The analysis of factors responsible for program continuity was undertaken. It was found that among 39 municipalities, $23(59 \%)$ have developed official recycling programs, 19 in partnership with scavenger associations. Indicators analysed showed that the programs resulted in social, and economic gains for scavengers, increased social capital and they contributed to the reduction of waste destined for landfills. However, there are competition factors that have been threatening the continuity of those programs. Keywords: recycling, sustainability, domestic waste, waste management, scavenger, São Paulo, Brazil, association, municipality, metropolitan area.
\end{abstract}

\section{Introduction}

Only $6.4 \%$ of 5,670 Brazilian Municipalities have official waste recycling programs. In Metropolitan São Paulo 20,000 tons of domestic waste are collected daily. Due to widespread urbanization, and lack of adequate lots for landfills, many municipalities adopted recycling programs using scavengers as partners, in 
efforts to reduce costs, and environmental impacts and to promote social inclusion, and income generation.

The aim of this research was to evaluate waste recycling programs in partnership with scavenger associations, in Metropolitan São Paulo, to verify their social, economic, sanitary and environmental impacts in a sustainability perspective.

Methods used were bibliographical, and data research and structured interviews with representatives of 39 municipalities that form the Metropolitan area of São Paulo. Indicators analyzed for the evaluation of these programs were: percentage of inhabitants served and of materials recycled and wasted, materials sold, costs of the program, scavenger income, and benefits.

\section{Domestic waste recycling in Brazil}

In Brazil, regarding volume of waste produced, close to $60 \%$ has an inadequate destination, in spite of the fact that there has been improvement in this situation. In $1989,28.8 \%$ of domestic residues were disposed of in sanitary landfills, in 2000 this proportion had increased to $40.8 \%$ [1].

Among Brazilian municipalities that have official selective recyclable collection programs, close to $50 \%$ informed they had developed programs in partnership with organized scavengers, and 96 municipalities informed they were organizing scavengers for this purpose [2]. Among those, only 178 (3.25\% of all Brazilian municipalities with regular collection) informed that they collected recycling waste in $100 \%$ of their urban area. Also in the year 2000, 50 municipalities (that had started and interrupted waste recycling programs) pointed out as reasons for failure: lack of adequate place, no acceptance by the population and awareness lack of recycling importance [2].

This picture reveals that the majority of Brazilian municipalities have not solved in adequate manner the issue of solid waste management and that the traditional way presents a lot of problems, but new alternatives are very timid and have not been evaluated yet. Solid waste management in Brazil is a responsibility of local governments, but since the 1988 Constitution each municipality can either administer, and provide the service or give permission to others to do the service. In this last case the municipality only regulates and promotes the collection and disposal and nonofficial actors (enterprises, or organizations) may participate in the process. Partnerships with scavengers were developed in this context.

\section{Recycling programs in Metropolitan São Paulo}

A preliminary investigation through interviews with those responsible for solid waste management in local governments showed that, among the 39 municipalities of Metropolitan São Paulo, 23 (59\%) had official recycling programs and 19 developed them in partnership with scavenger organizations (cooperatives, or associations). In three of them the program was operated by private enterprises and in one by the municipality itself. Nevertheless, among the 
20 municipalities that did not have partnership with scavengers 11 informed they intended to do so in a short term.

\subsection{Recycling programs in partnership with scavenger organizations}

Our study was concentrated on 11 municipalities that had started the recycling program with partnership before December 2003, as we considered it was impossible to evaluate sustainability of programs less than one year old when we started our field study.

Table 1: $\quad$ Start of recycling programs and of partnership with scavengers in municipalities of Metropolitan São Paulo.

\begin{tabular}{|l|c|c|}
\hline \multicolumn{1}{|c|}{ MUNICÍPALITY } & Start of recycling & Start of partnership \\
\hline São Paulo & 1989 & 2003 \\
\hline Santo André & 1992 & 2001 \\
\hline São Bernardo & 1993 & 2000 \\
\hline Embu & 1994 & 1994 \\
\hline Barueri & 2000 & 2001 \\
\hline Poá & 2000 & 2004 \\
\hline Carapicuiba & 2001 & 2002 \\
\hline Diadema & 2001 & 2001 \\
\hline Santana de Parnaíba & 2001 & 2001 \\
\hline Itapecerica da Serra & 2002 & 2002 \\
\hline Jandira & 2002 & 2002 \\
\hline
\end{tabular}

As seen in Table 1, São Paulo municipality first started waste recycling in 1989. Three other local governments started from 1992 to 1994, following Agenda 21 recommendations, but only one adopted partnership with scavengers that early. The other seven municipalities started recycling only after 2000, some at the same time as the partnership mentioned. This experience thus is quite recent and is related to the great expansion of the market for recyclables in Brazil (due to technical progresses in the processing industries, to environmental education of a significant population portion; and overall to the unemployment crisis that has become quite acute in the Metropolitan area of São Paulo).

In six of the eleven municipalities studied, the program was developed by the Environment Secretary Bureau or Department, indicating correlation with the idea of environmental conservation. Only in one of them, two Secretary Bureaus were accounted for (Citizenship and Social Development and Housing and Environment). So, even though the partnership is supposed to promote social inclusion, there is little supervision by social services, or Secretary Bureaus.

The majority of these governments have partnership with only one scavenger organization (63.6\%); two with two; one with five (Diadema) and the city of São Paulo with fifteen cooperatives. In 2005, the total number of persons involved in the programs, by municipality, varied from 3 to 663. Apart from these extremes, eight municipalities involved from 15 to 70 persons and one, 282. In total, 1,273 scavengers were employed in these programs (Table 2). 
Table 2: $\quad$ Scavenger Organizations and scavengers employed in the programs with partnership, and growth percentages.

\begin{tabular}{|l|c|c|c|l|}
\hline Municipality & Cooperatives & $\begin{array}{c}\text { Members in } \\
\text { start }\end{array}$ & $\begin{array}{c}\text { Members in } \\
\mathbf{2 0 0 5}\end{array}$ & Growth \% \\
\hline Barueri & 1 & 38 & 36 & 5.3 \\
Carapicuiba & 1 & 12 & 37 & 208.33 \\
Diadema & 5 & 23 & 49 & 113.0 \\
Embú & 1 & 20 & 34 & 70.0 \\
Itapecerica da Serra & 1 & 25 & 15 & -40.0 \\
Jandira & 1 & 8 & 3 & -62.5 \\
Osasco & 1 & 0 & 0 & \\
Poá & 1 & 20 & 26 & 30.0 \\
Santana do Parnaíba & 1 & 65 & 58 & -10.8 \\
Santo André & 2 & 20 & 282 & 1300.0 \\
São Bernardo & 2 & 40 & 70 & 75.0 \\
São Paulo & 15 & 26 & 663 & 2450.0 \\
\hline Total & $\mathbf{3 2}$ & $\mathbf{2 9 7}$ & $\mathbf{1 2 7 3}$ & $\mathbf{3 2 8 . 6}$ \\
\hline
\end{tabular}

Data obtained shows a $328 \%$ growth in the number of members employed (that passed from 297 to 1,273). However, those numbers are not significant when compared to others from Metropolitan São Paulo (that has close to 18 million inhabitants and 1.3 million unemployed). The members of those organizations are also very reduced in comparison to the estimated number of 20,000 scavengers existing only in the municipality of São Paulo [3].

\subsection{Scavenger organizations' benefits and responsibilities}

The partnerships involve some benefits to the organizations or payment of some services by local governments. The main benefits, described in Table 3, are diffusion materials $(90.9 \%)$, technical training $(81.8 \%)$ and payment of truck drivers, and recyclable collection teams $(72.7 \%)$.

In the majority of the programs (10 out of 11) the local government also provides the area for selection installations, but in none the area is donated to the cooperative/association. This fact highlights that there is strong dependency of those organizations on the municipalities. Nevertheless, the support is usually stronger at the beginning of the programs and tends to diminish with time, when they are relatively consolidated (but, sometimes they jeopardize their continuity, or their improvement).

In those 11 municipalities recyclable collection varies greatly in form and in frequency. In seven of them collection is done at homes by organized scavengers; in five of them collection is done at homes by City Hall employees, or by a private company paid by local government; in six of them there is voluntary delivery by inhabitants in containers provided by local governments; in six delivery is done in some specific points of the municipality (as parks and schools); and in eight of them the reception of recyclables is at the selection centers. As can be observed, some municipalities have two, three or four types of collection. Regarding frequency, in seven municipalities collection is done once a week, and in four, twice a week. 
Table 3: $\quad$ Benefits provided by Municipalities to scavenger organizations.

\begin{tabular}{|l|c|c|} 
Benefit provided & N. municipalities & $\%$ municipalities \\
\hline Diffusion Material & 10 & 90.9 \\
Technical training & 9 & 81.8 \\
Truck drivers & 8 & 72.7 \\
Collection team & 7 & 63.6 \\
Payment of electricity bill & 6 & 54.5 \\
Payment of water bill & 5 & 45.5 \\
Service tax Isention & 4 & 36.4 \\
Lettering courses & 4 & 36.4 \\
Medical Assistance & 3 & 27.3 \\
Basic Food & 2 & 18.2 \\
Meeting Centre & 2 & 18.2 \\
Accident protection equipment & 2 & 18.2 \\
Free transportation & 1 & 9.1 \\
Accountant & 1 & 9.1 \\
Fuel & 1 & 9.1 \\
Payment of telephone bills & 0 & 0.0 \\
\hline
\end{tabular}

The criteria for selection of the organization or the scavengers involved in the partnership included: previous existence of the group of scavengers (4 municipalities); independent scavengers (4 municipalities); ex-scavengers working in not sanitary landfills (8 municipalities); unemployed (5 municipalities); ex-prisoners or ex-drug addicts (1 municipality). In some municipalities two or three criteria were used. Excepting São Paulo, which did not have inadequate landfills; most of the other municipalities involved people previously living surrounded by domestic waste. With a strong enforcement by the Environment State Agency (CETESB), those inadequate deposits were closed down or transformed in controlled landfills and human work was forbidden on them. Those people taken off the deposits were trained to organize themselves in associations or cooperatives and to work on selection centers.

Some of those organizations established a formal or legal partnership with the Municipality and some also established other partnerships, as can be seen in Table 4.

The partnerships involve training of the workers by non-governmental organizations, by university, or by the church; donation of recyclable material by private enterprises or condominiums; payment of campaigns or of educational material for awareness raising in the population; financial resources for equipments provided by state or federal government; buying of selected material by recycling industries.

It is important that some other partnerships help the operation of the program and allow the empowerment of the members of the associations. Among the 11 municipalities involved, $9(81.8 \%)$ developed activities to enforce, and improve management of the organization, either through public institutions or through universities' extension work. However, as mentioned, those activities tended to diminish after the consolidation of the partnership. 
Table 4: $\quad$ Types of partnerships for the recycling program.

\begin{tabular}{|c|c|c|c|c|c|c|}
\hline \multirow[b]{2}{*}{ Municipality } & \multirow[b]{2}{*}{$\begin{array}{l}\text { Formal } \\
\text { Partnership }\end{array}$} & \multirow[b]{2}{*}{$\begin{array}{c}\text { Legal } \\
\text { Instrument }\end{array}$} & \multicolumn{4}{|c|}{ Other partnerships } \\
\hline & & & $\begin{array}{c}\text { private } \\
\text { co }\end{array}$ & $\begin{array}{c}\text { State } \\
\text { Govern } \\
\text { ment }\end{array}$ & $\begin{array}{c}\text { Fed. } \\
\text { Govern } \\
\text { ment }\end{array}$ & $\begin{array}{c}\text { Other } \\
\text { institution }\end{array}$ \\
\hline São Paulo & yes & covenant & & & & \\
\hline Barueri & yes & covenant & & & & \\
\hline Carapicuíba & yes & - & $\mathrm{X}$ & & & $\mathrm{X}$ \\
\hline Diadema & in process & Municipal law & & & & $\mathrm{x}$ \\
\hline Embu & no & Law Project & $x$ & $x$ & & \\
\hline Itapecerica da Serra & in process & covenant & & $x$ & & \\
\hline Jandira & in process & covenant & & & & \\
\hline Poá & Yes & covenant & & X & $\mathrm{X}$ & \\
\hline Santana de Parnaíba & no & - & $x$ & & & \\
\hline Santo André & yes & covenant & & & $\mathrm{X}$ & \\
\hline São Bernardo do Campo & no & Municipal act & & $\mathrm{X}$ & $\mathrm{x}$ & $\mathrm{X}$ \\
\hline
\end{tabular}

\subsection{Environmental, economic, and social benefits}

Environmental, economic and social benefits of those programs are related to the volumes of solid waste collected and sold by the organizations. Their sustainability also depends on those amounts.

The municipalities investigated collect from 60 to 8,700 tons of regular solid waste per day. Six of them collect up to 160 tons per day (56.6\%); four collect from 250 to 800 tons per day (36.4\%); and the municipality of São Paulo collects 8,700 tons per day. Those extreme, and varied numbers expose the also extreme demographic, social, and economic realities of the municipalities of the region.

However only four of the eleven municipalities know the composition of their garbage, and have undertaken gravimetric analysis in the last 5 years. In those cities, the following percentages of organic waste were verified: Diadema $50.9 \%$, Santo André 59.3\%, São Paulo 60.8\%, and Poá 69.9\%.

Among the 11 municipalities, 4 (36.4\%) throw their no recycled waste in sanitary landfills and $7(63.7 \%)$ in controlled landfills. All of them collect, in a regular basis, residues from 75 to $100 \%$ of their population. But regarding the percentages of their populations served by the collection of recyclable waste, they were as follows: $0-10 \%$ in 3 municipalities $(27.3 \%) ; 20-30 \%$ in four municipalities (36.4\%); $50-75 \%$ in one municipality $(9.1 \%)$ and $75-100 \%$ in 2 municipalities $(18.2 \%)$. One representative of a municipality did not know the percentage. These data indicate that in the majority of them $(63.7 \%)$ the collection of recyclables reaches only up to $30 \%$ of their populations. This can be considered a low index. Only Santo André and Barueri reach high index of coverage. 
Table 5: $\quad$ Coverage of the recycling program.

\begin{tabular}{|c|c|c|c|c|}
\hline \multirow{2}{*}{ Municipality } & \multirow{2}{*}{$\begin{array}{l}\text { Population - } \\
2004 \text { - IBGE }\end{array}$} & \multicolumn{3}{|c|}{ Coverage of the program in $\mathrm{N}$. of inhab. } \\
\hline & & minimum & maximum & $\%$ * \\
\hline São Paulo & 10838581 & & 3251574 & very low \\
\hline Barueri & 248034 & 186026 & 248034 & high \\
\hline Carapicuíba & 375859 & & 112758 & very low \\
\hline Diadema & 383629 & & 115089 & very low \\
\hline Embu & 234174 & 117087 & 175631 & average \\
\hline Itapecerica da Serra & 152283 & - & - & nd \\
\hline Jandira & 106742 & & 32023 & very low \\
\hline Poá & 105805 & & 31742 & very low \\
\hline Santana de Parnaíba & 93845 & & 28154 & very low \\
\hline Santo André & 665923 & 499442 & 665923 & high \\
\hline São Bernardo do Campo & 773099 & & 231930 & very low \\
\hline $\begin{array}{l}\text { * Coverage: } \\
0-30 \% \text { - very low } \\
30-50 \% \text { - low } \\
50-75 \% \text { - } \\
75-100 \% \text { - high }\end{array}$ & & & & \\
\hline
\end{tabular}

The volumes of recyclables collected by those official programs, in partnership with scavengers, vary from 25 tons per month to 2,340 tons per month. In eight municipalities the amounts do not reach 150 tons per month; one collects 500 tons per month and the city of São Paulo collects 2,340 tons per month. One representative did not know the volume. In the municipality of São Paulo, given the scale of the program and the high number of inhabitants (more than 10 millions in the year 2000), the numbers are quite impressive and justify the development of activities related to reprocessing those materials. Even though, considering the production of 8,700 tons/day of waste in the municipality, the amount recycled is very low. In the other municipalities the volumes collected for recycling are quite small and the efficiency of the system is not very good, as the percentages of useless waste can reach up to $50 \%$, as can be observed in Table 6 .

According to the Municipality's representative, the sale of these materials generated incomes to the organizations that varied from US\$ 450.00 to US\$ $15,000.00$ per month. But eight representatives of local governments could not inform their respective organization's income. Information regarding income received by members of the scavenger organizations were obtained from representatives of Municipalities, and checked in interviews with presidents of the organizations. Their income varied from US\$ 50.00 to US\$260.00 per month. In four municipalities it was less than Brazil's minimum income wage in 2005 (US\$ 130.00), but in five cities it was from US\$207.00 to US\$ 260.00 monthly. Two representatives did not have the information.

Representatives of 8 local governments also did not have information about the program's total costs. If this lack of information can be considered positive (revealing autonomy of the organizations regarding distribution of their economic resources) in another perspective it also reveals these programs' lack 
of monitoring, and result evaluation by local governments. This fact is particularly worrying because ten among the eleven municipalities studied had plans for enlarging the program in the following 12 months; and many other local governments in Brazil are copying this model (without basis of knowledge on their social and economic sustainability). Also because a strong dependency on revenues generated by the sale of recyclables, and on government help was observed. Only one association had a second source of financial resource, which was guaranteed by a contract to collect waste for the local government.

Table 6: $\quad$ Recyclables collected, sold and \% of waste informed.

\begin{tabular}{|l|c|c|c|}
\hline \multicolumn{1}{|c|}{ Municipality } & $\begin{array}{c}\text { Collected } \\
\text { (ton/month) }\end{array}$ & $\begin{array}{c}\text { Sold } \\
\text { (ton/month) }\end{array}$ & $\begin{array}{c}\text { Percentage of } \\
\text { waste informed }\end{array}$ \\
\hline São Paulo & 2340 & 1670 & 10 to $20 \%$ \\
\hline Barueri & 150 & 130 & 10 to $20 \%$ \\
\hline Carapicuíba & 40 & $\mathrm{~ns}$ & $\mathrm{Na}$ \\
\hline Diadema & 54 & 44 & $10.4 \%$ \\
\hline Embu & 62 & 52 & 10 to $20 \%$ \\
\hline Itapecerica Serra & 30 & $\mathrm{~ns}$ & $-5 \%$ \\
\hline Jandira & $\mathrm{ns}$ & 3 & 10 to $20 \%$ \\
\hline Poá & 25 & 23 & $-5 \%$ \\
\hline Santana Parnaíba & 70 & $\mathrm{~ns}$ & $35 \%$ \\
\hline Santo André & 500 & 250 & $50 \%$ \\
\hline São Bernardo & 88 & $\mathrm{na}$ & $\mathrm{Na}$ \\
\hline Total & 3359 & 2172 & \\
\hline
\end{tabular}

Another point is that, since these programs are also meant for social inclusion, it is important to know their members' income in order to define how many more workers can be hired to the organizations. The authors consider that an income twice the amount of the national minimum wage could guarantee a social inclusion and be a signal for the possibility of integrating new members.

As seen, the amounts of recyclables collected and sold through these programs in partnership with scavengers are quite low, considered the amount of waste collected and disposed of in São Paulo Metropolitan area. Environmental sustainability of the solid waste management certainly does not depend on those programs. Many improvements are necessary to guarantee the social, economic, and environmental sustainability of these programs. However, seven among the eleven municipalities considered that the program is consolidated in their cities because inhabitants consider it important and would not accept its interruption; on the other hand, scavengers wish expansion of the program because of the social benefits it brings: education, training, and more stability.

\section{Challenges to the programs}

In our investigation, the people interviewed listed some of the major problems faced by the programs in their municipalities. Eight of them indicated as a major 
problem competition with no organized scavengers that collected recyclables prior to official collection on the streets. This was made more interesting because in many areas there is sorting of the waste in the households. Even though in terms of avoiding waste to go to landfills there is a benefit in this process, in terms of increasing social capital in the associations there is a loss. As mentioned, only in the city of São Paulo, an estimated number of 20,000 people collect recyclable waste in an informal way. As causes of problems faced we can point: 1. Little or no experience of the members of the cooperatives in management of an association, insufficiency of technical formation and weak participation of the members in the decisions result in lack of organization and problems of relationship among members. More and more frequent courses and advising are necessary to solve these. 2. Since scavengers revenues depend solely on the sale of materials and their price is low and decreasing, due to competition, they face lack of working capital to improve their infra-structure and to buy equipments, but also to buy recyclables from independent scavengers and to advance payments to the members of the cooperative before the end of the month. One of the reasons pointed for the high turnover of the members is that the autonomous scavenger can sell what they collect everyday and face his expenses daily. To enhance scavengers' participation in the cooperative system, including the payment for their work, is a recommendation. 3. Municipalities indicated that there is still much to do in terms of awareness of residue sorting importance and getting a stronger participation of the population. Awareness raising campaigns and the implementation of a waste tax according to the volume of residues produced in each household could increase the amount of material collected and also diminish the volume of waste in the selection centers.

Some indicators are recommended for monitoring the sustainability of these programs: waste tax; legal instrument of partnership; partnerships; percentages of inhabitants served, of material recycled, and of waste within the recyclables. In table 7 are indicated sustainability indicators for the associations.

Table 7: $\quad$ Sustainability Indicators for the Associations.

\begin{tabular}{|l|c|c|c|}
\hline \multicolumn{1}{|c|}{ Indicator } & \multicolumn{1}{c|}{ - } & +/- \\
\hline 1.Regularized association & Regularized & Non regularized & \\
\hline 2. Partnership legal instrument & Law or contract & No contract & Covenant \\
\hline 3. Annual turnover of members & Up to $25 \%$ & More than $50 \%$ & From 25 to50\% \\
\hline 4.Capacity building of members & Incubation & No capacity building & Courses \\
\hline 5. Members' monthly income & 2 minimum wages & 1 minimum wage & From 1 to 2 \\
\hline 6.Participation of members & High & Low & Average \\
\hline 7. Triage Centre & Owned by Coop & Lent & Rented \\
\hline 8.Equipments/Vehicles & Owned by Coop & Lent & Owned/lent \\
\hline 9.Hours worked daily & Over 6 & Up to 4 & From 4 to 6 \\
\hline 10.Benefits to members & 3 or more & none & Less than 3 \\
\hline 11.IPE & Use IPE & Don't have IPE & No use \\
\hline 12.N. of partnerships & 2 or more & None & Less than 2 \\
\hline
\end{tabular}




\section{Conclusions}

Organizations still depend much on municipalities and the programs have low efficacy, and efficiency. Municipalities invest resources, but they do not use indicators to evaluate, and improve their activities. Organizations feel doubtful about program continuity, and its revenue guarantee. Programs present aspects related to social inclusion, social capital formation, and generation of work positions at a low cost. However, many aspects must be strengthened

\section{Acknowledgement}

We thank Funasa - Fundação Nacional de Saúde - for providing funds for the study.

\section{References}

[1] IBGE - Instituto Brasileiro de Geografia e Estatística. Pesquisa Nacional de Saneamento Básico 2000. Rio de Janeiro, Brasil: 2002a.

[2] IBGE - Instituto Brasileiro de Geografia e Estatística. Indicadores de Desenvolvimento Sustentável. Rio de Janeiro, Brasil: $2002 \mathrm{~b}$.

[3] Borges, Danielle. Prefeitura de São Paulo. Aumenta número de distritos com coleta seletiva. Jornal Diário de São Paulo. September 29, 2005. São Paulo, Brazil. 